\title{
The Necessity of Moral Principles in Moral Education
}

\author{
Emmanuel Jerome Udokang \\ http://dx.doi.org/10.4314/ujah.15i2.1
}

\section{Abstract}

Many well-meaning parents and teachers are hamstrung in their attempts at moral education of their children and wards. Hence they are caught in some dilemma. On the one hand, if they incline toward the code of conception, they tend to be authoritarian in their approach; if, on the other hand, they favour some variant of the romantic reaction, they may expect that children will go it alone and decide it all for themselves. To overcome this dilemma, there is need for a synthesis of both alternatives. It is precisely the synthesis of these two positions (principles and creativity) that we propose to explore in this paper as a preliminary to any discussion on moral education. With analytic method as a tool, the paper concludes that until a more adequate view of morality which embroils the proper place for both authority and self-directed learning is synthesized, a discourse on moral education will be of no good.

\section{Introduction}

It is not difficult to understand that content is crucial in education. But there is a point where the romantic banners of "development," "growth," and "discovery" is raised especially when children are being bored or bullied (notably in United States of America). But romanticism is always valuable as a protest. Another sort of trouble would start when romantics themselves get into positions of authority and demand that children shall scamper around being "creative" and spontaneously "discovering" what it has taken civilized men 
centuries to understand. Some synthesis has to be worked out between established content and individual inventiveness. The basis for such a synthesis is to be found mainly in those public historically developed modes of experience whose immanent principles enable individuals to build up and revise an established content and to make something of themselves within it. In science, for instance, merely learning a lot of facts is a weariness of the spirit; but a man untutored in a scientific tradition, could not ask a scientific question, let alone exhibit "creativity". Originality is possible only for those who have assimilated some content and mastered the mode of experience, with its immanent principles, by means of which this content has been established and repeatedly revised.

The same sort of Hegelian progression is detectable in morality. Morality to many still conjures up a code prohibiting things relating to sex, stealing, and selfishness. The very word "code" suggests a body of rules, perhaps of an arbitrary sort, that all hang together but that have no rational basis. To others, however, morality suggests much more individualistic and romantic notions, such as criterionless choices, individual autonomy, and subjective preferences. Whether one experiences anguish in the attempt to be "authentic," or proclaims, like Bertrand Russell, that one simply does not like the Nazis, the picture is roughly the same - that of the romantic protest. Synthesis must be sought by making explicit the mode of experience which has gradually enabled civilized people to distinguish what is a matter of morals from what is a matter of custom or law, and which has enable them to revise and criticize the code in which they have been brought up, and gradually to stand on their own feet as autonomous moral beings. This they could never have done without a grasp of principles.

It is the details of this sort of synthesis that we propose to explore in this paper as a preliminary to any discussion of 
moral education; for it is no good talking about moral education until we have a more determinate conception of what is involved in being "moral." Because they are uncertain about this, many well-meaning parents and teachers are hamstrung in their attempts at moral education. If they incline toward the code of conception, they tend to be authoritarian in their approach; if, on the other hand, they favour some variant of the romantic reaction, they may expect that children will go it alone and decide it all for themselves. A more adequate view of morality should reveal the proper place for both authority and self-directed learning in moral education. The nature of principles requires to be examined.

\section{The Nature of Principles}

A place for principles in the moral life must be insisted on without making too far-flung claims for what they can prescribe without interpretation by means of a concrete tradition. Indeed we want to insist on the importance of such traditions for the learning of principles as well as for their interpretation. Before, however, this theme is developed in detail, more must be said about the nature of principles in order to remove widespread misunderstandings.

First of all, what are principles? A principle is that which makes a consideration relevant. Suppose that a man is wondering whether gambling is wrong and, in thinking about this, he takes account of the misery caused to the families of gamblers he has known. This shows that he accepts the principle of considering people's interests, for he is sensitized to the suffering caused by gambling rather than horror-struck at the amount of greenness in the world created by the demand for green tables. He does not, in other words, accept the principle of the minimization of greenness. He may or may not be able to formulate it and to defend it against criticism, as some, like Oakeshott (1962) and Dancy (2004: 2) who are 
allergic to principles, suggest. Rather it depends on whether a man is sensitized to some considerations and not to others.

Of course, formulation is necessary if one intends to embark on some moral philosophy in the attempt to justify principles. And it might well be said that the task of justifying them is a crucial one for anyone who is according them the importance we are according them. There are a limited number of principles which are fundamental but non-arbitrary in the sense that they are presuppositions of the form of discourse in which the question "What are the reasons for doing?" is asked seriously. The principles which have this sort of status are those of impartiality, the consideration of interests, freedom, respect for persons, and probably truthtelling. Such principles are of a procedural sort in that they do not tell us precisely what rules there should be in a society but lay down general guidance about the ways in which we should go about deciding such matters and indicate general criteria of relevance. It was argued that these principles are presuppositions of what is called the democratic way of life, which is based on the conviction that there is a better and a worse way of arranging our social life and that this should be determined by discussion rather than by arbitrary fiat (Ozumba 2001, 43).

Even if it is granted that arguments along these lines might be sustained for a few fundamental principles, further difficulties might still be raised. It might be said, for instance, that stress on the importance of principles in morality implies rigidity in the moral life. A picture is conjured up of Hardylike characters dourly doing their duty while the heavens fall about them. Certainly some kind of firmness is suggested by the phrase "a man of principle." But here again, there are misunderstandings. A man of principle is one who is consistent in acting in the life of his sensitivity to aspects of a situation that are made morally relevant by a principle. But 
this does not preclude adaptability due to differences in situations, especially if there is more than one principle which makes different factors in a situation morally important.

A more usual objection to belief in such fundamental principle is that they are not absolute. But there is an ambiguity in this type of objection. Absolute can be used as opposed to relative or related to a particular culture. There are the usual arguments about the relativity of particular rules in this sense and the failure of many in the world to place much store by a principle like that of fairness. There is a lack of consensus. Science would be in a poor plight if it depended on universal consensus. Most people in the world do not think this way and never have. Does this affect either Newton's laws or - more importantly - the rational procedures by means of which they have been tested? What does it matter if there are some people in the Pacific who do not think it important to be fair? They do not do geometry either or test their assumptions by experiment.

Once the form of thought - be it science or morality has developed, a certain kind of autonomy and absoluteness goes with it. A man who thinks rationally in these spheres cannot give up the law of non contradiction and many other principles which are presupposed in the general attempt to decide matters on the basis of reason. A rational man can no more give up, in the moral sphere, the principle that he should consider people's interests than he can, in the scientific sphere, give up the principle that he should decide between alternative hypotheses in the light of the observational evidence. But a degree of absoluteness at this level is compatible with a vast amount of change and relativity at lower levels. The history of science (whether empirical or otherwise) is the history of assumptions that have either been discarded or found to be valid only under certain limited conditions. But what have not been discarded are the 
principles of procedure by reference to which assumptions have been accepted or rejected. Similarly with morality; a certain degree of absoluteness at the level of fundamental principles is quite compatible with change and "relativity" at a lower level.

Absolute, on the other hand, can be contrasted with prima facie rather than with "Relative". These two are often confused and they generate a lot of rather muddled thinking. Often those who are opposed to "absolute" principles have in mind another type of consideration which is much more pertinent. They maintain that principles or basic rules cannot be "absolute" because there are circumstances in which they have to be bent a bit. What about "white lies" for instance? What about breaking a promise to save someone else's life? Do not circumstances alter cases?

Of course, they do - provided that the circumstances fall under some other principle. All principles or rules are subject to an "other things being equal" clause. And things are not equal if another principle is relevant to the situation. If there is more than one fundamental principle, it must sometimes be the case that there is a conflict. A person has to act in such cases and whatever he does one of his principles is infringed. A "white lie" ( that is, withholding of truth to serve life), for instance, is not one told for gain or glory. It is one told when telling the truth might, for instance, cause untold suffering. A choice has to be made between telling the truth and causing great suffering. One principle has to be infringed. Which is it likely to be? But just because there are some cases like this where a principle has to be infringed, nothing follows about the general duties involved. The general duty to tell the truth is not undermined by the fact that on rare occasions other duties are more urgent.

There are, for instance, many whose life has been haunted by the necessity of making such agonizing choices 
between duties. They tend, therefore, to think of all morality in terms of individual decision and choice. This is surely an exaggerated and over-dramatic view of how we are placed. Such conflicts and agonies could not arise unless we have first come to realize that certain duties were incumbent on us. And we could not sensibly be said to "choose" between alternatives unless we first had principles which made alternatives morally relevant. And it is nonsense to say that as children we "choose" o decide for ourselves that things like lying or breaking promises are wrong.

Talk of individual decision and of "commitment" is, of course, the obverse side of the acceptance of relativism. For if you do not believe that there is any possibility of people making mistakes about moral matters you either shrug your shoulders and stick to the tradition in which you have been brought up, or you make a fuss about individual choice. And people draw attention to individual choice more or less apologetically. Individual choice, in our view, is very important in the development of character and in the application of rules to particular cases - either when there is a clash between rules or when there is a more straightforward clash between duty and inclination. But it should not be extended to cover the whole area of morals - especially the acceptance of general principles and basic rules. How many of us have ever "decided" that lying is wrong or have "chosen" not to murder our neighbours?

Another time-honoured objection is that principles are products of reason and hence inert. We may mouth them or assent to them, but this may be a substitute for acting in a morally appropriate way. Part of the answer to this objection is to be found in the answer to the criticism that links having principles with the ability to formulate them and to defend them. But there is a further point that needs to be made. Notions such as "fairness" and "the consideration of interests" 
are not affectively neutral. "That is unfair" is an appraisal which has more affinities with an appraisal such as "that is dangerous" than it has with a colourless judgment such as "that is oblong." Pointing out that someone is in pain is not at all like pointing out that he is five feet six inches tall.

The strength of the emotive theory of ethics derives from the fact that moral principles pick out features of situations which are not affectively neutral. This, however, does not make them inconsistent with living a life guided by reason; for this sort of life presupposes a whole constellation of such appraisals, e.g., that one should be consistent, impartial, and truthful, that one should have regard to relevance, accuracy, and clarity, and that one should respect evidence and other people as the source of arguments. It is only an irrationalist who welcomes contradictions in an argument, who laughs with delight when accused of inconsistency, or who is nonchalant when convicted of irrelevance. Science and any other rational activity presuppose such normative standards which are intimately connected with the passion for truth which gives point to rational activities. Unless people cared about relevance and had feelings about inconsistency science would not flourish as a form of human life. The usual contrast between reason and feeling is misconceived; for there are attitudes and appraisals which are the passionate side of the life of reason.

So much, then, for the usual objections to the conception of the moral life in which prominence is accorded to principles. Sure, we have said enough to establish their place in it. Let us now show how they can be seen to function in relation to concrete traditions to which MacIntyre ascribes so much importance and how they can save us from the existentialist predicament which he views as the logical alternative to being encased in a surviving code. But before 
delving to this discussion, let us first discuss the function of principles.

\section{The Function of Principles}

There are some, like Alasdair MacIntyre (1967), McNaughton (2000, 256-275), Martha Nussbaum (2001, 310) who seems to hold that we have no middle way between allegiance to a surviving code and some kind of romantic protest. For, it is argued, moral terms such as "good" and "duty," once had determinate application within a close-knit society with clear-cut purposes and well-defined roles; but now, because of social change, they have broken adrift from these concrete moorings. A pale substitute is left in generalized notions such as "happiness" instead of concrete goals, and duty for duty's sake instead of duties connected with role performances that were manifestly related to the goals of the community. So we have a kind of moral schizophrenia in the form of irresolvable conflicts between "interest" and "duty" and no determinate criteria for applying these general notions, because their natural home has passed away. It is no wonder, on this view, that those who have not been brought up in one of the surviving tribalism make such a fuss about commitment and criterionless choice; for there is nothing else except those ancient realities to get a grip on.

\section{The Birth of a Rational Morality Based on Principles}

Science and, of course, a more rational, universalistic type of morality emerged precisely because social change, economic expansion, and conquest led to a clash of codes and to conflict between competing views of moralities in the world. Men were led to reflect about which story about the world was true and which code was correct. In discussing and reflecting on these matters they came to accept higher order 
principles on a procedural sort for determining such questions, hence the birth of a rational morality based on principles.

MacIntyre applauds people like Spinoza who drew attention to values connected with freedom and reason. He admits the supreme importance of truth-telling; he notes the massive consensus about basic rules for social living first emphasized by the natural law theorists, which H. L. Hart (1961) revived as the cornerstone of a moral system. But why was MacIntyre so unimpressed by this consensus that he gives such one-sided presentation of the predicament of modern man? It is mainly so, it seems, because an appeal to such principles and basic rules cannot give specific guidance to any individual who is perplexed about what he ought to do.

\section{Difficulties about Concrete Guidance}

Two connected difficulties are incorporated in this type of objection to principles. The first, already mentioned, is that no concrete guidance can be provided by them for an individual who wants to know what he ought to do. This is usually illustrated by the case of the young man who came to Sartre wanting guidance about whether he should stay at home and look after his aged mother or go abroad and join the Free French (Oyeshile 1997, 186). How could an appeal to principles help him? Well, surely he only had a problem because he already acknowledged duties connected with his status as a son and as a citizen. Would Sartre have said to him "You have to decide this for yourself" if the alternative to joining the Free French has been presented as staying at home and accepting bribes from the Germans for information? And surely if what is claimed to be missing is a principle for deciding between these duties, there are principles which would rule out some reasons which he might give for pursuing one of the alternatives. Supposing, for instance, he said that he was inclined toward going abroad because he wanted to 
determine precisely the height of St. Paul's Cathedral; would Sartre have applauded his exercise of criterionless choice?

The existentialist emphasis on "choice" is salutary, of course, in certain contexts. It is important, for instance, to stress man's general responsibility for the moral system which he accepts. This needs to be said against those who smugly assume that it is just there to be read off. It needs to be said, too, in the context of atrocities such as Belsen. It also emphasizes the extent to which character is destiny and the role which choices play in shaping the individual's character. In this kind of development, conflict situations are particularly important, and if fundamental principles conflict there is not much more that one can say than that the individual must make up his own mind or use his judgment. But we do not decide on our fundamental principles such as avoiding pain or being fair; still less do we "choose" them. Indeed, we would feel very uneasy in dealing with a man who did. And why should a moral theory be judged by its capacity to enable the individual to answer the question "What ought I do now?" as distinct from the question" What, in general, are there reasons for doing?

Do we expect casuistry from a moral philosopher or criteria for making up our own minds?

The more important difficulty is the one MacIntyre (1967: 24) observed; that fundamental principles such as "fairness" or "considering people's interests" give us such abstract criteria that they are useless because they always have to be interpreted in terms of a concrete tradition. We are very sympathetic to this objection, but I think that it also applies in varying degrees to all rational activities. To take a parallel: all scientists accept some higher order principle such as that one ought to test competing hypotheses by comparing the deduced consequences with observations. But this does not give them 
concrete guidance for proceeding. It has to be interpreted. To start with, what is to count as an observation? The amount of social tradition and previous theory built into most observation procedures, especially in the social sciences, is obvious enough. And how is the importance of one set of observation to be assessed in relation to others? This is not unlike saying in the moral case: the suffering of people is affected impartially by a social practice. But what is to count as suffering and how is one person's suffering to be weighed against another's? But do difficulties of this sort render the procedural principles of science useless? If not, why should fundamental moral principles be regarded as useless?

Fundamental principles of morality such as fairness and the consideration of interests only give us general criteria of relevance for determining moral issues. They prescribe what sort of considerations are to count as reasons. Within such a framework we have to work out arrangements for organizing their lives together. And just as in science there is a fair degree of consensus at a low level of laws, so in the moral case there are basic rules, for example, concerning contracts, property, and the care of the young, which any rational man can see to be necessary to any continuing form of social life, man being what he is and the conditions of life on earth being what they are. For, given that the consideration of interests is a fundamental principle of morality and given that there is room for a vast amount of disagreement about what, ultimately, a man's interests are, there are nevertheless certain general conditions which it is in any man's interest to preserve however idiosyncratic his view of his interests. These include not only the avoidance of pain and injury but also the minimal rules for living together of the type already mentioned. Above this basic level there is room for any amount of disagreement and development. People are too apt to conclude that just because some moral matters are controversial and variable, for 
instance sexual matters, the whole moral fabric is unstable. It is as if they reason: In Africa men have several wives, in Europe only one, in U.S.A only one at a time; therefore all morals are a matter of taste! As evils, murder and theft are just as culture-bound as spitting in the street!

The point surely is that stability and consensus at a basic level are quite compatible with change and experiment at other levels. Indeed to expect any final "solution," any secure resting place in social or personal life, is to be a victim of the basic illusion which is shared by most opponents of democracy, that of belief in some kind of certainty or perfection. But in determining what basic rules are and in seeking above this level ways of living which may be improvements on those we may have inherited, we make use of principles. Such principles have to be interpreted in terms of concrete traditions; they cannot prescribe precisely what we ought to do, but at least they rule out certain courses of action and sensitize us to features of a situation which are morally relevant. They function more as signposts than as guidebooks.

Let us now show how principles can be seen to function in relation to concrete traditions to which MacIntyre ascribes so much importance and how they can save us from the existentialist predicament which he views as the logical alternative to being encased in a surviving code.

\section{The Complexity and Concreteness of the Moral Life}

A man who accepts principles is too often represented as living in some kind of social vacuum and attempting to deduce from his principles a concrete way of living. This is an absurd suggestion. To start with, the disposition to appeal to principles is not something that men have by nature, any more than reason itself is some kind of inner gadget that men switch on when the occasion arises. If thinking is the soul's dialogue with itself, the dialogue within mirrors the dialogue without. 
To be critical is to have kept critical company, to have identified oneself with that segment of society which accepts certain principles in considering its practices. Rationality, of which science is a supreme example, is itself a tradition. Rational men are brought up in the tradition that traditions are not immune from criticism.

But criticism, thinking things out for oneself, and other such activities connected with a rational type of morality, cannot be exercised without some concrete content. For how can one be critical without being brought up in something to be critical of? In other words, to be critical is to be critical of something. Again, how can one think things out for oneself unless one's routines break down or one's roles conflict? Adherence to principles must not be conceived of as selfcontained; it must be conceived of as being bound up with and modifying some kind of content. Scientists cannot think scientifically without having any content to think about.

\section{Complexity}

In an open society this content is considerably more complex than in those small, self-contained communities where, according to MacIntyre, concepts such as "good" and "duty" had their natural home. The notion, for instance, that people are persons with rights and duties distinct from those connected with their roles is an alien notion in such close-knit communities. But once this is admitted, as was widely the case with the coming of Stoicism and Christianity, the content of the moral life becomes immediately much more complicated. For the norms connected with treating people as persons begin to interpenetrate those connected with roles and with the accepted goals of life. In trying to get a clear idea, therefore, about the contours of our moral life it is necessary to consider its complexity before we can grasp the concrete 
ways in which principles enter into it. At least five facets of our moral life must be distinguished (Sidgwick 1987, 15).

First of all, under concepts such as "good," "desirable," and "worthwhile," fall those activities which are thought to be so important that time must be spent on initiating children into them. These include things such as science, poetry, and engineering and possibly a variety of games and pastimes. Most of these are intimately connected not only with occupations and professions but also with possible vocations and ideals of life. In our type of society they provide a variety of options within which an individual can make something of himself if he is encouraged to pursue his own bent as the principle of freedom demands.

Second, under the concepts of "obligation" and "duty," fall ways of behaving connected with social roles. Much of a person's moral life is taken up with his station and its duties, with what is required of him as a husband, father, citizen, and member of a profession or occupation.

Third, there are those duties, more prominent in an open society, which are not specifically connected with any social role but which relate to the following of general rules governing conduct between members of a society. Rules such as those of unselfishness, fairness, and honesty are examples. These affect the manner in which an individual conducts himself within a role as well as in his noninstitutionalized relationships with others. They are personalized as character traits.

Fourth, there are equally wide-ranging goals of life which are personalized in the form of "motives." These are purposes not confined to particular activities or roles, which derive from non-neutral appraisals of a man's situation. Examples are ambition, envy, benevolence, and greed. An ambitious man, for instance, is one who is moved by the thought of getting ahead of others in a whole variety of 
contexts. Both traits of character and motives can be thought of as virtues and vices. The traits of fairness and honesty are virtues; those of meanness and selfishness are vices. The motives of benevolence and gratitude are virtues; those of greed and lust are vices. Both character traits and motives, when looked at in a justificatory context, incorporate considerations that can be regarded as fundamental principles. Examples would be fairness and benevolence, which can be appealed to in order to criticize or justify not only other traits and motives, but also conduct covered by activities and role performances.

There are, finally very general traits of character which relate not so much to the rules a man follows or to the purposes he pursues as to the manner in which he follows or pursues them. Examples would be integrity, persistence, determination, conscientiousness, and consistency. These are all connected with what used to be called "the will."

The point is spelling out this complexity of our normal life to rid us straightaway of any simple-minded view that moral education is just a matter of getting children to have "good personal relationships" or to observe interpersonal rules like those relating to sex, stealing, and selfishness. It emphatically is not. To get a boy committed to some worthwhile activity, such as chemistry or engineering, is no less part of his moral education than damping down his selfishness; so also is getting him really committed to the duties defining his role as a husband or teacher. These duties, of course, must be interpreted in a way which is sensitized by the principle of respect for persons; but no adequate morality could be constituted purely out of fee-floating personal obligations. ${ }^{11}$ 


\section{Concreteness}

So much for the complexity of the content of the moral life which is to form the basis for any rational morality that appeals to principles. Let us now turn to the matter of concreteness in the interpretation of fundamental principles and moral ideals. The burden of the attack on principles by people like MacIntyre, Dancy and Winch is to be found in Edmund Burke (1992); it is that they are too abstract. The lines of morality are not like the ideal lines of mathematics. Our contention is that principles can be conceived of and must be conceived of as entering into the moral life in a perfectly concrete way without making them completely culture-bound.

Impartiality. The most fundamental principle of all practical reasoning is that of impartiality. This is really the demand that excludes arbitrariness, which maintains that distinctions shall be made only where there are relevant differences. This is essential to reasoning, in that what is meant by a reason for doing $A$ rather than $B$ is some aspect under which it is viewed which makes it relevantly different. But though this principle gives negative guidance in that it rules out arbitrariness, making an exception of oneself, and so on, it is immediately obvious that it is quite impossible to apply without some other principle which determines criteria of relevance. The most obvious principle to supply such criteria is that of the consideration of interests, which is personalized in virtues such as benevolence and kindness.

The Consideration of Interests. In practice the rays of this principle are largely refracted through the prism of our social roles and general duties as members of a society. If we are teachers, for instance, considering the people's interests amounts, to a large extent, to considering the interests of children entrusted to our care. I once taught with a man who 
had such a wide-ranging concern for people's interests that he used to tell his class to get on with some work and to sit there with them, writing letters to old scholars, in order to get them to subscribe to an "Aid to India" fund. His present scholars were, of course, bored to death! He certainly had a somewhat abstract approach to considering people's interests!

Most utilitarians, following Mill and Sidgwick, have stressed the importance of Mill's "secondary principles" in morality. The utilitarian, Mill argued, has not got to be constantly weighing the effects of his actions on people's interests any more than a Christian has to read through the Bible every time before he acts. The experience of a society with regard to the tendencies of actions in relation to people's interests lies behind its roles and general rules. The principle that one should consider people's interests acts also as an ever-present corrective to, and possible ground of criticism of, to rules and social practices which can also be appealed to when rules conflict. This point is well made by Stephen Toulmin (1950) in his book on ethics. A man could stick too closely to his role and accept too uncritically what was expected of him generally as a member of society. He might be very much an organization man or a man of puritanical disposition, riddled with rules that might have lost their point, or without sensitivity to the suffering caused by unthinking insistence on the letter of the law. What would be lacking would be that sensitivity to suffering caused by actions and social practices which finds expression in virtues such as benevolence, kindness, and what Hume called "the sentiment of humanity" (Nurry 1997, 143).

Freedom. Giving interpersonal support to the consideration of interests is the principle of freedom which lays it down that other things being equal, people should be allowed to do what they want, or that, in others, reasons should be given for 
constraining people in their pursuit of what they take to be good (Kant 1999, 133).

This combines two notions, that is "wants" and that of "constraints," and immediately the concrete questions crowd in "What is it that people might want to do?" and "What sorts of constraints should be absent?" What, too, is to count as a constraint? Is it the want to walk about nude or to speak one's mind in public that is at issue? And are the constraints those of the bully or those of public opinion? The situation becomes even more complicated once we realize that, men being what they are, we are only in fact free from obnoxious constraints like of the bully if we are wiling to accept the milder and more leveling constraints of law. And so concreteness asserts itself. The principle only provides a general assumption, albeit one of far-reaching importance. At what point we decide that there are good reasons for constraining people because, for instance, they are damaging the interests of others, is a matter of judgment.

Closely related to the principle of freedom are ideals like "the self-development of the individual" and personal autonomy. But here again, concreteness is imperative, for what can "development" mean unless we build into the concept those modes of experience that it has taken the human race so long to evolve? And what sort of "self" is going to develop? Granted that this must come to a certain extent from the individual, who does this partly by his "choices," must not this "self" be fairly closely related to the normal stock of motives and character traits which are called virtues? And is it not desirable that higher order character traits, such as persistence and integrity, be exhibited in the development of "self"? And how can the pressure for independence and the making of choices arise unless the individual genuinely feels conflicting obligations deriving from his occupancy of social roles and his acceptance of the general rules of society? And 
what point is there in choice unless the individual thinks that what he decides can be better or worse, wise or foolish? And if he thinks that any particular act is not a pointless performance he must already accept that there are general principles which pick out relevant features of the alternatives open to him.

All of this adds up to the general conclusion that the ideals connected with the principle of freedom are unintelligible except against a background of desirable activities, roles, and rules between which the individual has to choose and that any proper choice (as distinct from random plumping) presupposes principles other than freedom in the light of which alternatives can be assessed.

Respect for Person (Timmermann 2008, 76). The same sort of point can be made about respect for persons, another fundamental principle which underlies and acts as corrective to so many of our formalized dealings with other men. Indeed, much of the content of this principle has to be defined negatively in such concrete contexts. To show lack of respect for a person is, for instance, to treat him in a role situation as merely a functionary, to be impervious to the fact that he, like us, has aspirations that matter to him, is a center of evaluation and choice, takes pride in his achievements, and has his own unique point of view on the world. Or it is to treat him merely as a participant in an activity who is to be assessed purely in terms of his skill and competence in that activity. Worse at something becomes generalized to worse as a human being. In a similar way an excess of group loyalty or fellow-feeling can make a man seem not just different in some respects but generally inferior as a human being. Respect for persons, too, is at the bottom of our conviction that some motives are vices - lust, for instance, and envy and a certain kind of humility. 


\section{Conclusion}

Our task was to show the place of moral principles in moral education in a society where the child's freedom to make choices for himself is emphatically emphasized. While the child's freedom is to be respected, it must also be acknowledged that the child cannot be allowed to make all decisions for himself. He must be guided by the rules already accepted as moral principles in the society. However, synthesis must be sought by making explicit the mode of experience which has gradually enabled civilized people to distinguish what is a matter of morals from what is a matter of custom or law, and which has enable them to revise and criticize the code in which they have been brought up, and gradually to stand on their own feet as autonomous moral beings. Such revision and critique would not have been possible but for the existence of moral principles which they must of necessity grasp. Hence, a discourse on moral education will be of no good if there is no synthesis between principles and self-directed learning. It is against this background that the romanticists' attack on moral principles crumbles.

\section{Emmanuel Jerome Udokang}

Department of Philosophy and Religions

University of Benin, Benin-City

Edo State 


\section{References}

Dancy, J. 2004. Ethics without Principles. Oxford: Oxford University Press.

Hart, H.L. 1961. The Concept of Law. London: Oxford University Press.

Kant, I. 1999 Groundwork of the Metaphysics of Moral. Tran. H. J. Paton, New York: Hafner Press.

MacIntyre, A. 1967. A Short History of Ethics. London: Routledge and Kegan Paul.

Nurry, J. 1997. Hume and Kant. London: Darton Press.

Nussbaum, M. C. 2001. The Fragility of Goodness, Luck, and Ethics in Greek Tragedy and Philosophy. Revised Edition. Cambridge: Cambridge University Press.

Oakeshott, M.1962. The Tower of Babel. Rationalism in Politics. London: Methuen.

Oyeshile, O. 1997. Sartre's Ontology and the Subjectivity of the Individual. The Great Philosophers vol. II.. Aba: AAU. 182-212.

Ozumba, G. 2001. Theories of Ethics. Aba: AAU.

Peters R. S. 1966. Ethics and Education. London: Allen and Unwin.

Peters, R. S. 1967. The Status of Social Principles and Objectives in a Changing Society. The Educational Implications of Social and Economic Change. School 
Council Working Paper No.12. London: Her Majesty's Stationery Office.

Rawlings, M and Rawlings, P. 2000. Unprincipled Ethics. Moral Particularism. Brad Hooker and Margaret Olivia Little (Eds.). Oxford: Oxford University Press.

Scheffler, I. 1966. Philosophy and Education. Second Edition. Boston: Allyn and Bacon.

Sidgwick, D. 1987. Five Theories of Ethic. New York: McGraw-Hill.

Toulmin, S. C. 1950. The Place of Reason in Ethics. Cambridge: Cambridge University Press.

Timmermann, J. 2008. Kant's Groundwork of the Metaphysics of Morals: A Commentary. New York: Cambridge University press. 